\title{
Screening of microscopic fungi and their enzyme activities for decolorization and biotransformation of some aromatic compounds
}

\author{
T. Korniłłowicz-Kowalska • K. Rybczyńska
}

Received: 6 September 2013/Revised: 5 June 2014/ Accepted: 12 July 2014/Published online: 29 July 2014

(C) The Author(s) 2014. This article is published with open access at Springerlink.com

\begin{abstract}
A total of 610 strains from 16 species of micromycetes with potential ligninolytic capabilities were isolated from soil, compost, and rotten wood, including 400 strains of soil origin. In the test of decolorization of agarized $0.06 \%$ alizarin blue, 52 strains with high decolorization activity were selected. In liquid cultures with $0.2 \%$ post-industrial lignin and $0.03 \%$ alizarin blue, all of the selected strains showed three different extracellular peroxidase activities such as HRP-like, LiP, and MnP. Laccase was detected only in the cultures with alizarin blue, but those were trace amounts. In the decolorization of alizarin blue, the highest levels of activity were attained by HRPlike peroxidase. In the transformations of post-industrial lignin that included decolorization, colorization (darkening of substrate), and re-colorization, the highest levels of activity were attained by lignin peroxidase, especially at the start of the culture. The transformations of both dye substrates in the cultures of all 52 strains were accompanied by the release of glucose oxidase, but high activities of that enzyme were observed only in the presence of alizarin blue. Whereas in the presence of lignin the fungi under study synthesized catalase, the activity of which attained a
\end{abstract}

Electronic supplementary material The online version of this article (doi:10.1007/s13762-014-0656-2) contains supplementary material, which is available to authorized users.

T. Korniłłowicz-Kowalska ( $₫) \cdot$ K. Rybczyńska Laboratory of Mycology, Department of Environmental Microbiology, University of Life Sciences, ul. Leszczyńskiego 7, 20-069 Lublin, Poland

e-mail: teresa.kornilowicz@up.lublin.pl maximum toward the end of the culture was negatively correlated with the activity of the remaining oxidoreductases under study. Among the 52 selected strains, three strains such as Haematonectria haematacocca BwIII43, K37, and Trichoderma harzianum BsIII33 were characterized by a high activity of decolorization.

Keywords Micromycetes - Anthraquinone dye - Lignin · Decolorization - Extracellular oxidoreductases

\section{Introduction}

The cellulose-paper industry and the textile industry produce the greatest amounts of dye pollutants. The textile industry produces 800,000 tons of wastes annually, and the scale of production of liquid wastes from that sector increases constantly. In terms of the level of pollutants released to the environment, the cellulose-paper industry is among the top 5 world producers. In a year, approximately 455 million tons of paper are produced globally, 1 ton of paper products requiring the use of from 90.922 to $272.766 \mathrm{dm}^{3}$ of water (Nemerow and Dasgupta 1991; Garg and Modi 1999). The industrial production of paper products generates wastewaters containing highly toxic compounds (Amat et al. 2005). Cellulose pulping with the Kraft method results in the production of mainly alkaline lignin, thiolignin, terpenes, phenols, and lignin sulfonates, while the effects of its bleaching are inorganic chlorine compounds, chlorine derivatives of lignin, dioxins, chlorophenols, guaiacol, and catechol (Chakar and Ragauskas 2004; Pokhrel and Viraraghavan 2004). Among colored industrial wastes, an important group of pollutants are effluents from wool and silk dying, containing degradation-resistant anthraquinone dyes, mainly alizarin ones (Guzel and 
Akgerman 2000). Industrial anthraquinone dyes are synthesized on the basis of 9,10-anthraquinone, and they are characterized by high fastness and efficiency in the process of dying (Allen and McKellar 1978). Due to their structure, chemical properties, and method of application, those dyes are classified among acid dyes, mordant dyes, direct dyes, or reactive dyes (Holme 2002). To achieve fast color, the dyes are bound in the presence of a so-called chelating agent, i.e., salts of metals: $\mathrm{Cr}^{+3}, \mathrm{Co}^{+3}$, and $\mathrm{Cu}^{+2}$ (Holme 2002; Uddin and Hossain 2010). The anthraquinone dyes used in the textile industry are characterized by a high resistance to degradation and to changes in the physicochemical conditions of the environment, and therefore, they must be neutralized before they can be released into the environment. Effluents containing mordant dyes are potentially the most toxic, as apart from the dye substances they also contain ions of heavy metals, formaldehyde, organic compounds of chromium, as well as sulfur and nitrates. Due to the presence of organic compounds that may react with, e.g., chlorine during their disinfection, the effluents from the textile industry constitute a serious threat to the environment and to human health (Kant 2012).

In recent years, there is an increasing interest in the ligninolytic capabilities of microfungi that, similar to the basidiomycetes of the so-called white rot of wood, can degrade a broad spectrum of aromatic compounds. The possibility of the application of micromycetes for the purposes of bioremediation of the environment is indicated by the fact that certain species, e.g., from the genera Fusarium, Aspergillus, Penicillium, and Trichoderma, degrade PAHs, including anthracene, the precursor of synthetic dyes (Colombo et al. 1996; Wu et al. 2010).

Information currently available on the subject of decolorization of post-industrial lignin and dyes with aromatic structure by microscopic fungi is fragmentary and does not provide any more extensive data on the enzymes that participate in that process (Rodriguez et al. 1996; Jarosz-Wilkołazka et al. 2002; Lopez et al. 2006; Lozovaya et al. 2006; Anastasi et al. 2009; Biyik 2012), whereas studies concerning ligninolytic basidiomycetes show that the processes of decolorization and biodegradation of lignin and related compounds, including anthraquinone dyes, proceed with the participation of peroxidases and (or) laccase (Shin 2004; Champagne and Ramsay 2005; Korniłłowicz-Kowalska and Rybczyńska 2012).

The objective of the study was the screening and isolation of microfungi decolorizing alizarin blue and postindustrial lignin, analysis of their capabilities of biosynthesis of "decolorization enzymes," and estimation of the activity of those enzymes and certain auxiliary enzymes in the process of decolorization.

\section{Materials and methods}

\section{Sources of strains}

The strains used for this work were isolated from three different sources: habitats (soil, compost) and substrate (rotting wood) from Poland. The samples of soil (black earth, Phaeozemes acc. to FAO; humus field $3.61 \%, \mathrm{~N}_{\text {tot. }}$. $0.290 \%$, and $\mathrm{pH}_{\mathrm{KCl}} 7.3$ ) were collected from an arable field, a mature compost $\left(\mathrm{C}_{\text {org. }} 498.7\right.$ and $\mathrm{N}_{\text {tot }} .19 .44 \mathrm{~g} \mathrm{~kg}^{-1}$ dry matter) obtained from plant debris $(25.53 \%$ pine bark $10.63 \%$ wheat straw, $51.06 \%$ sawdust), and rotten wood of deciduous trees $\left(\mathrm{C}_{\text {tot. }} .42 .40 \%, \mathrm{~N}_{\text {tot. }} .5 \%\right)$ obtained from forests.

\section{Culture media composition}

The media used in the experiments were as follows: according to Lopez et al. (2006)-1.6 $\mathrm{K}_{2} \mathrm{HPO}_{4}, 0.5$ $\mathrm{KH}_{2} \mathrm{PO}_{4}, 0.58 \mathrm{MgSO}_{4} \cdot 7 \mathrm{H}_{2} \mathrm{O}, 0.25 \mathrm{NaCl}, 1.25\left(\mathrm{NH}_{4}\right)_{2} \mathrm{SO}_{4}$, $1 \mathrm{NH}_{4} \mathrm{NO}_{3}, 0.13 \mathrm{CaCl}_{2} \cdot 2 \mathrm{H}_{2} 0,0.0025 \mathrm{FeCl}_{3} \cdot 6 \mathrm{H}_{2} 0,20$ agar in $\mathrm{g} \mathrm{dm}^{-3}$ with $0.25 \%$ glucose and $0.06 \%$ of Alizarin Blue Black B, Sigma, or $0.03 \%$ of textile industry blue or $0.2 \%$, post-industrial lignin; Park and Robinson medium (Park and Robinson (1969)): $0.2 \mathrm{KH}_{2} \mathrm{PO}_{4}, 0.1 \mathrm{NH}_{4} \mathrm{NO}_{3}$, $0.5 \mathrm{MgSO}_{4} \cdot 7 \mathrm{H}_{2} \mathrm{O}$ in $\mathrm{g} \mathrm{dm}^{-3}$; nutrient agar: 10 glucose, 5 peptone, 3 yeast extract, 20 agar in $\mathrm{g} \mathrm{dm}^{-3}$, PDA agar20.0 potato, 20.0 glucose, 20.0 agar in $\mathrm{g} \mathrm{dm}^{-3}$.

Isolation and identification of fungi

\section{Soil}

Lignin $(10 \mathrm{~g})$ in bags of polyamide $-6(5 \times 5 \times 6 \mathrm{~cm}, \phi$ pores of $0.5 \mathrm{~mm}$ ) - was introduced to the depth of ca. $5 \mathrm{~cm}$ from surface of soil placed in glass vessels with volume of $1,000 \mathrm{~cm}^{3}$. After adjusting the soil moisture to the level of $50 \%$, the height of the soil layer was ca. $25 \mathrm{~cm}$. Incubation was performed at room temperature $\pm 2{ }^{\circ} \mathrm{C}$ for 6 months. Isolation of pure cultures was performed with the use of solid medium according to Lopez et al. (2006) with $0.25 \%$ glucose and $0.06 \%$ of alizarin blue, Sigma, $0.03 \%$ of textile blue or $0.2 \%$ post-industrial lignin on which clods of the substrate were placed using a preparation needle. Cultures were incubated at $28{ }^{\circ} \mathrm{C}$ for 10 days. Pure cultures of the fungi strain were transferred on PDA slants.

\section{Compost}

Isolation of fungi from compost was performed, using a liquid medium according to Lopez et al. (2006) with $0.25 \%$ glucose and $0.2 \%$ post-industrial lignin inoculated 
with $2.5 \mathrm{~g}$ of the compost. The cultures were incubated at $30{ }^{\circ} \mathrm{C}$ in rotatory shaker at $130 \mathrm{rpm} \mathrm{min}{ }^{-1}$. The growing mycelia were transferred onto fresh medium and incubated for 14 days under the same conditions. After 14 days, the procedure was repeated. Isolation of pure cultures was performed with plate dilution method using nutrient agar and a medium according to Lopez et al. (2006) with $0.2 \%$ post-industrial lignin. The cultures were incubated at $28{ }^{\circ} \mathrm{C}$ for 7 days. The growing colonies of fungi were transferred on PDA slants.

\section{Rotten wood}

Isolation of fungi from wood infested with rot was performed with the method of placing small fragments of wood on the solid medium according to Lopez et al. (2006) with $0.25 \%$ glucose and $0.2 \%$ post-industrial lignin and incubated at $28{ }^{\circ} \mathrm{C}$ for 10 days. Pure cultures were transferred on PDA slants.

Identification of pure fungal cultures to genera and species was conducted on the basis of macroscopic and microscopic observations (Domsch et al. 1980; Kwaśna et al. 1991). The genera and species names of the fungi were given in conformance with the current nomenclature (http://www.indexfungorum.org).

\section{Screening on model dye in solid conditions}

Preselection of the decolorization properties of the collected microfungi was performed on agarized medium according to Lopez et al. (2006) with $0.06 \%$ alizarin blue (Sigma) enriched with $0.25 \%$ glucose. For further analyses, those strains were selected, which gave the largest zone of decolorization of alizarin blue within the shortest time. The degree of decolorization was calculated from the formula:

$\mathbf{D}=\frac{\varnothing \mathrm{p}-\varnothing \mathrm{d}}{\varnothing \mathbf{p}} \times \mathbf{1 0 0}$

where $\mathbf{D}$ is the degree of decolorization of the culture medium in $\%$; $\varnothing \mathbf{p}$ is the diameter of Petri dish $(90 \mathrm{~mm})$; $\varnothing \mathbf{d}$ is the diameter of decolorization zone ( $\mathrm{mm})$

For the estimation of the decolorization abilities, the following scale of value of D was accepted: $1-10 \%$-very weak; 11-20\%-weak; 21-40\%-moderate; 41-70\%strong; $>70 \%$ very strong.

Screening on model dye and post-industrial lignin in liquid conditions

Fungal strains were cultivated in $100 \mathrm{~cm}^{3}$ of Erlenmeyer flasks containing $50 \mathrm{~cm}^{3}$ of liquid Parka and Robinson medium (1969), with $0.25 \%$ glucose and $0.03 \%$ alizarin blue or $0.2 \%$ post-industrial lignin supplemented. The inoculum $\left(1 \mathrm{~cm}^{3}\right)$ was a suspension of spores $\left(5 \cdot 10^{7} \mathrm{~cm}^{-3}\right)$ obtained by rinsing 7-day cultures of the fungal strain studied, on the PDA slants, with $5 \mathrm{~cm}^{3}$ of $0.9 \% \mathrm{NaCl}$. The cultures were incubated for 14 days at $28{ }^{\circ} \mathrm{C}$, in three parallel replicates. The control treatment consisted of cultures without any addition of dye substrates and a medium not inoculated with fungi.

\section{Decolorization activity}

The decolorization activity of the selected strains was measured spectrophotometrically by periodic measurements of absorbance of clear post-culturing fluids, after determining the maxima of absorbance: for alizarin blue$\mathrm{A}_{526 \mathrm{~nm}}$ and for the post-industrial lignin- $-\mathrm{A}_{430 \mathrm{~nm}}$. The control was the medium not inoculated with fungi. The degree of decolorization of the post-culturing fluids was determined according to the formula of Lopez et al. (2006):

$\%$ decolorization $=\frac{\mathbf{A} \mathbf{i}-\mathbf{A f}}{\mathbf{A} \mathbf{i}} \times \mathbf{1 0 0}$

(where \% decolorization is the degree of decolorization of the culture medium in $\%, \mathbf{A}_{\mathbf{i}}$ is the initial absorbance, and $\mathbf{A}_{\mathbf{f}}$ is the final absorbance).

Enzyme assays

Enzymatic activity in the post-culturing fluids was assayed spectrophotometrically. Activity of horseradish-type peroxidase (HRP-like) was assayed according to the method of Maehly and Chance (1954) in the modification of Malarczyk (1984), using $0.01 \%$ o-dianisidine $\quad\left(\varepsilon_{460 \mathrm{~nm}}=\right.$ $11.3 \mathrm{M}^{-1} \mathrm{~cm}^{-1}$ ) as the substrate in $0.1 \mathrm{M}$ acetate buffer, $\mathrm{pH} 5.5$, in the presence of $0.1 \mathrm{mM} \mathrm{H}_{2} \mathrm{O}_{2}$. Activity of manganese-dependent peroxidase $(\mathrm{MnP})$ was assayed through oxidation of $1 \mathrm{mM} \mathrm{MnSO}_{4}$ in $50 \mathrm{mM}$ of sodium malonate, $\mathrm{pH} 4.5$, and in the presence of $0.2 \mathrm{mM} \mathrm{H}_{2} \mathrm{O}_{2}$ and then the determination of the complex $\mathrm{Mn}^{+3}$-malonic acid $\left(\varepsilon_{270 \mathrm{~nm}}=11,59 \mathrm{M}^{-1} \mathrm{~cm}^{-1}\right)$ according to the method was described by Wariishi et al. (1992). Activity of lignin peroxidase (LiP) was estimated according to Tien and Kirk (1988) using $20 \mathrm{mM}$ of veratryl alcohol $\left(\varepsilon_{310 \mathrm{~nm}}=9\right.$, $3 \mathrm{M}^{-1} \mathrm{~cm}^{-1}$ ) in $40 \mathrm{mM}$ of tartrate buffer, $\mathrm{pH} 3$, in the presence of $0.4 \mathrm{mM} \mathrm{H}_{2} \mathrm{O}_{2}$. Activity of laccase (Lac) was measured according to Leonowicz and Grzywnowicz (1981) using syringaldazine $\left(\varepsilon_{525 \mathrm{~nm}}=6.5 \mathrm{M}^{-1} \mathrm{~cm}^{-1}\right)$ as the substrate, in $0.1 \mathrm{M}$ citrate-phosphate buffer, $\mathrm{pH} 5$. Activity of glucose oxidase (GOX) was assayed according to Lloyd and Whelan (1969) in glycerol triphosphate buffer, $\mathrm{pH}$ 7.0, with an admixture of o-dianisidine and horseradish peroxidase (Sigma, Peroxidase Type II From Horseradish $) \quad\left(\varepsilon_{525 \mathrm{~nm}}=1.86 \mathrm{M}^{-1} \mathrm{~cm}^{-1}\right)$. Activity of 
catalase (CAT) was estimated according to Aebi (1984) using $10 \mathrm{mM} \mathrm{H}_{2} \mathrm{O}_{2}\left(\varepsilon_{240 \mathrm{~nm}}=39.40 \mathrm{M}^{-1} \mathrm{~cm}^{-1}\right)$. In the assays of the enzymatic activity, the control was the medium inoculated with fungi but without any addition of the dye substrates.

For all the enzymes studied, the adopted unit of enzymatic activity was the specific activity $\left(\mathrm{mU} \mathrm{mg}^{-1}\right)$ of protein. In all assays, one milli unit of specific enzyme activity $\left(\mathrm{mU} \mathrm{mg}^{-1}\right)$ was defined as the amount of enzyme that oxidized $\mu$ mol substrate per minute under defined condition. The specific activity of enzyme was measured at $1 \mu$ moles $\mathrm{mg}^{-1}$ protein. The protein concentration was determined by the Lowry method using bovine serum albumin as a protein standard (Lowry et al. 1954).

Data analysis

Data concerning the activity of extracellular oxidoreductases in cultures of the strains studied, containing $0.03 \%$ of alizarin blue and $0.2 \%$ of post-industrial lignin, were subjected to statistical analysis using the program STATISTICA version 10 (StatSoft, Poland). The relationships between the features studied over the whole period of the study were analyzed with the method of correlation and regression, calculating the coefficient of correlation $r$ and determining the function of curvilinear regression and the coefficient of determination $R^{2}$. The regression functions are cubic polynomials. Characteristics of the enzymes studied on the particular dates of experiments were expressed with values of the variation index $\mathrm{Cv}(\%)$, which describes variability in the percentage of the mean value in relation to the mean value, and the coefficient of interclass variability $h^{2}(\%)$. It denotes what percentage of the total variability of a given feature results from differentiation in the study object (i.e., fungi strains). $\mathrm{Cv}$ and $h^{2}$ were calculated according to the fallowing formula:

$\mathrm{Cv}=\frac{\mathrm{SD}}{\bar{x}} \cdot 100 \% \quad h^{2}=\frac{\mathrm{SSa}}{\mathrm{SSt}} \cdot 100 \%$

(SD is the standard deviation, $\bar{x}$ is the arithmetic mean, $\mathrm{SSt}=\mathrm{SSa}+\mathrm{SSe}$ is the components of variance referring to, respectively, SSt, total variation; SSa, object (strain) variation); and $\mathrm{SSe}$, intra-object variation (random).

\section{Results and discussion}

Screening of potentially ligninolytic microfungi

Using post-industrial lignin as the substrate, preliminary isolation yielded 610 potentially ligninolytic strains: 400 from the soil (Phaeozems according to FAO), 200 from the compost of lignin-cellulose wastes, and 10 from wood infested with rot. Within the accumulated collection of soil fungi, the most frequently isolated were the following: Haematonectria haematococca (=Fusarium solani)-156 strains (39\%), Clonostachrys rosea f. catenulata (=Gliocladium catenulatum) -112 strains $(28 \%)$, and Clonostachrys rosea f. rosea (=Gliocladium roseum) -60 strains $(15 \%)$. Lower frequencies $(5 \%)$ were the characteristic of the species Fusarium oxysporum (20 strains) and Trichoderma harzianum (20 strains). The remaining 32 strains represented the species (from 2 to $3 \%$ ): Aspergillus flavus, A. ustus, and Penicoillium verrucosum (Table 1). The strains isolated from the compost were mainly fungi from the genus Aspergillus, primarily A. fumigatus-146 strains $(73 \%)$ and less frequently $(10 \%)$ A. flavus-20 strains. Other potentially ligninolytic fungi isolated from the composts were classified as Aspergillus niger, Absidia spinosa, Phaeostalagmus cyclosporus, Aphanoascus keratinophilus, T. harzianum, and Penicillium expansum. They represented from 2 to $3 \%$ of the strains of those fungi. Potentially ligninolytic microfungi isolated from rotten wood represented solely $H$. haematococca.

Decolorization abilities of micromycetes, including such genera and species as Aspergillus, Penicillium, Cladosporium, Scopulariopsis, Stachybotrys, F. solani, F. oxysporum, and T. harzianum, have been reported by various authors (Rodriguez et al. 1996; Waffaa et al. 2003; Anastasi et al. 2009; Gao et al. 2011; Andleeb et al. 2012; Neoh et al. 2012).

The screening of micromycetes with decolorization capabilities, performed in this study, indicates that such abilities are frequently encountered in natural communities of those microorganisms and especially in the soil environment. It was also demonstrated that the decolorization abilities of mold fungi as well as of wood white-rot basidiomycetes are coupled with their capabilities of transformation of lignin and the simpler aromatic compounds (Korniłłowicz-Kowalska et al. 2006, 2008; Korniłłowicz-Kowalska and Rybczyńska 2012).

The role of the soil as a reservoir of microscopic fungi with abilities of biodegradation of lignin and industrial dyes was showed earlier by other authors (Falcón et al. 1995; Rodriguez et al. 1996; Raju et al. 2007; Husseiny 2008; Korniłłowicz-Kowalska et al. 2008; Bi et al. 2012). Undoubtedly, that is determined by the abundance of various aromatic compounds of plant and microbiological origin in the soil, and of lignin and products of its degradation in particular.

Selection of strains with decolorization capabilities on solid media

Among the 610 potentially ligninolytic strains, 226 $(37.2 \%)$ strains displayed an ability of decolorization of 
Table 1 Estimation of decolorization abilities of strains of potentially ligninolytic microfungi in plate test with $0.06 \%$ Alizarin Blue Black B

\begin{tabular}{|c|c|c|c|c|c|c|c|}
\hline \multirow[t]{2}{*}{ Strains } & \multirow[t]{2}{*}{ Number of strains } & \multicolumn{6}{|c|}{ Rate of decolorization (in \%) } \\
\hline & & $\mathrm{ND}^{\mathrm{a}}$ & $1-10$ & $11-20$ & $21-40$ & $41-70$ & $>70$ \\
\hline Absidia spinosa & 1 & - & - & - & - & - & 1 \\
\hline Aspergillus flavus & $32(12)^{b}$ & 29 & - & 1 & 2 & - & - \\
\hline Aspergillus fumigatus & 146 & 143 & 3 & - & - & - & - \\
\hline Aspergillus niger & $14(11)^{\mathrm{b}}$ & 14 & - & - & - & - & - \\
\hline Aspergillus sp. & $3^{\mathrm{b}}$ & - & - & - & - & - & 3 \\
\hline Aspergillus ustus & $4^{\mathrm{b}}$ & 3 & - & - & - & 1 & - \\
\hline Aphanoascus keratinophilus (=Chrysosporium keratinophilium) & 1 & 1 & - & - & - & - & - \\
\hline Fusarium oxysporum & $20^{\mathrm{b}}$ & 12 & - & 2 & 2 & 4 & - \\
\hline Haematonectria haematococca (=Fusarium solani) & $178(156)^{\mathrm{b}}$ & 35 & 6 & 18 & 36 & 48 & 35 \\
\hline Clonostachrys rosea $f$. catenulata (=Gliocladium catenulatum) & $112^{\mathrm{b}}$ & 77 & - & 3 & 9 & 7 & 16 \\
\hline Clonostachrys rosea f. rosea $(=$ Gliocladium roseum $)$ & $60^{\mathrm{b}}$ & 35 & - & 3 & 7 & 9 & 6 \\
\hline Penicillium expansum & 1 & 1 & - & - & - & - & - \\
\hline Penicillium verrucosum & $2^{\mathrm{b}}$ & 2 & - & - & - & - & - \\
\hline Phaeostalagmus cyclosporus & 1 & - & - & - & - & - & 1 \\
\hline Rhinotrichum lanosum & 12 & 12 & - & - & - & - & - \\
\hline Trichoderma harzianum & $23(20)^{\mathrm{b}}$ & 19 & - & 2 & 1 & 1 & - \\
\hline Total & 610 & 383 & 9 & 29 & 57 & 70 & 62 \\
\hline
\end{tabular}

${ }^{a}$ Not detected

${ }^{\mathrm{b}}$ Strains of microscopic fungi isolated from soil

$0.06 \%$ alizarin blue on solid media. In accordance with the adopted scale of decolorization abilities, 62 strains $(10.2 \%)$ showed very strong ability of decolorization of that dye (decolorization $>70 \%), 70$ strains $(11.5 \%)$ strong (decolorization from 41 to $70 \%$ ), and 57 strains $(9.3 \%$ ) moderate ability of decolorization of $0.06 \%$ alizarin blue (21-40\%). The remaining 38 strains had weak or very weak abilities of decolorization of agarized $0.06 \%$ alizarin blue (Table 1).

Most frequently, abilities of decolorization of $0.06 \%$ alizarin blue on solid media were noted for strains of $H$. haematococca ( $80.3 \%$ of strains of that species), followed by Clonostachrys rosea f. catenulata (41.7\% of isolates), C. rosea f. rosea (31.2\%), F. oxysporum (40\%), and $T$. harzianum $(17.4 \%)$. Very seldom, in spite of numerous representation, decolorization capabilities were demonstrated by strains of Aspergillus spp. (5\% of isolates) (Table 1).

Within the particular species, there was notable differentiation among the strains in terms of their decolorization capabilities. Next to strains with weak abilities of decolorization of $0.06 \%$ alizarin blue on solid media, there were strains in which that feature was expressed strongly or very strongly. That effect, due to the numerous representations of strains, was the most observable in the case of $H$. haematococca, Clonostachrys rosea $f$. catenulata, and $C$. rosea $f$. rosea (Table 1).

Our studies with the use of alizarin blue indicate that decolorization capabilities are encountered most frequently among $H$. haematococca (=F. solani) and less often among the genera so common in natural environments as Aspergillus and Penicillium. It was showed that ca. $40 \%$ (out of 400 studied) of strains of fungi of soil origin (Pheozems according to FAO), displaying the ability of decolorization of alizarin blue, represented $H$. haematococca (=F. solani), and $43 \%$ Clonostachrys rosea (=Gliocladium), represented by 2 species: $C$. rosea $f$. catenulata and $C$. rosea $f$. rosea. Common occurrence of those abilities among $H$. haematococca is indicated also by the fact that out of the total of 178 potentially ligninolytic strains isolated (isolates from the soil, compost, and wood infested by rot), 143 strains, i.e., $80 \%$, were capable of decolorization of alizarin blue. The common occurrence of capabilities of lignin biodegradation among strains of $H$. haematococca $(=F$. solani) could thus explain the ability of decolorization of alizarin blue frequently observed among those fungi. The abilities of strains of $F$. solani for biodegradation of lignin coupled with abilities of decolorization of various dyes, including anthraquinonic ones, have been reported earlier by Rodriguez et al. (1996), Anastasi et al. (2009), Biyik 
(2012), Lozovaya et al. (2006), Norris (1980), Abedin (2008).

Decolorization activity in liquid cultures

The study included 52 strains of micromycetes, which, after 2 weeks of growth on agar media with $0.06 \%$ alizarin blue, removed $70 \%$ of the dye (Table 1). The exception was strain T. harzianum BsIII33, which was characterized by fast decolorization already in the first days of growth on a medium with alizarin blue, even though the rate of decolorization subsequently decreased. The selected strains represented 7 species: $H$. haematococca (25 szczepów), $C$. rosea f. catenulata (16), C. rosea f. rosea (5), Aspergillus spp. (3), P. cyclosporus (1), A. spinosa (1), and T. harzianum (1).

In liquid cultures, all of the selected 52 strains systematically lightened the color of the medium caused by $0.03 \%$ alizarin blue (Fig. 1). The decolorization was the most intensive in the first week of the culturing, when the loss of color was from 10 to $56 \%$ (average from 20 to $45 \%$ ). Ultimately, the lightening of the medium was not complete but amounted to from 30 to $65 \%$ (Fig. 1). The strain differentiation of the ability of decolorization of alizarin blue was notable $\left(R^{2}=0.42\right)(23.88-41.78 \%$ coefficient $\mathrm{Cv}$; 50.47-77.63\% coefficient $h^{2}$ ). The highest degree of decolorization of $0.03 \%$ solutions of alizarin blue was the characteristic of strain T. harzianum BsIII33, which, after 4 days, removed $70 \%$ of that dye.

However, in the available literature lacks the information about decolorization of alizarin blue by microorganisms, whereas data are available that indicate the decolorization of other anthraquinone dyes by white- and brown-rot fungi: Remazol Brillant Blue R (RBBR), Basic Blue 22, Poly R-478 (a polyanthraquinone dye) (Freitag and Morrell 1992; Jarosz-Wilkołazka et al. 2002; Eichlerová et al. 2005, 2007; Lozovaya et al. 2006; Rigas and Dritsa 2006; Raju et al. 2007; Anastasi et al. 2009; Yemendzhiev et al. 2009; Korniłłowicz-Kowalska and Rybczyńska 2012). Based on our study, we concluded that certain of the selected strains of microfungi, e.g., $H$. haematococca and $C$. rosea $f$. catenulata, already after 4 days, while $T$. harzianum after 2 days, caused 40, 50, and $65 \%$, respectively, decolorization of $0.03 \%$ solutions of the monoanthraquinone dye used. Raju et al. (2007), using lower doses $(0.02 \%)$ of another monoanthraquinone dye (Blue 3R), after 4 days of culturing of strains of A. flavus, F. oxysporum, F. moniliforme, and T. harzianum, obtained decolorization at levels of $82.5,36.6,28.8$, and $22.4 \%$, respectively.

Our research showed that all of the selected 52 strains were capable of biotransformation of post-industrial lignin. However, they differed in the mechanism of the process, which comprised decolorization or (and) colorization (darkening of the medium). Medium lightening during 14-day cultures with $0.2 \%$ post-industrial lignin was recorded in the case of 28 strains (Table 2). In the cultures of the remaining 24 strains (unpublished data), an increase in color intensity was primarily observed (darkening of the substrate). In the former group of strains, the decrease in the color intensity was clearly observable in the first week and usually did not exceed $40 \%$. Certain strains, e.g., $H$. haematococca BS5 and L25, after 2-3 days removed even as much as $90 \%$ of the color caused by $0.2 \%$ postindustrial lignin (Table 2). Over a longer period of time, among the "decolorizers" of lignin, a decrease was usually observed in the degree of decolorization. Decolorization of lignin solutions was the most stable in the case of 3 strains of $H$. haematococca: Bs11, BwIII43, and K37, strains $C$. rosea f. catenulata BsII74, Aspergillus LII11, and T. harzianum BsIII33 (23-33\%). Analysis of regression performed to determine the relationships between lignin decolorization and the time of culturing (based on the results for the 28 fungal "decolorizers") supports the tendency toward a reduction in the degree of lignin decolorization with increasing duration of culturing (Fig. 1). However, in view of the very low coefficient of determination, that is, a measure of fit of the regression functions to the experimental data, the obtained dynamic model of the process of decolorization of $0.2 \%$ lignin by microscopic fungi cannot be accepted as satisfactory. This results from the fact that the microfungi under study, during the decolorization of $0.2 \%$ post-industrial lignin, showed very high variability, which usually exceeded $90 \%$ (76.72-95.80\% coefficient $\mathrm{Cv}$ ), and was determined in ca. $70 \% \quad\left(54.86-86.19 \%\right.$ coefficient $\left.h^{2}\right)$ by the strain variability.

It was noted that the lightening of the solutions of postindustrial lignin appeared primarily in cultures of $H$. haematococca, while their darkening was observed more often in the case of Clonostachrys rosea. This would indicate differences in the mechanism of biotransformation of lignin, perhaps determined by the diversification of the spectrum of activities of enzymes participating in the process. This suggestion could be supported by the observations of Westermark and Eriksson (1974) made with relation to the white-rot basidiomycete Polyporus versicolor. According to those authors, re-colorization of lignin is related with the formation of quinones. Initially, under the effect of operation of ligninolytic enzymes, colorless phenolic compounds are liberated from lignin and then oxidized to color quinones (Westermark and Eriksson 1974). Korniłłowicz-Kowalska et al. (2008) reported that decolorization of lignin by white-rot fungi is accompanied with a decrease in the level of methoxyphenols. A drop in the level of methoxyphenols (unpublished data) was noted 
Fig. 1 Analysis of regression of decolorization of solutions of $0.2 \%$ post-industrial lignin and $0.03 \%$ Alizarin Blue Black B solutions

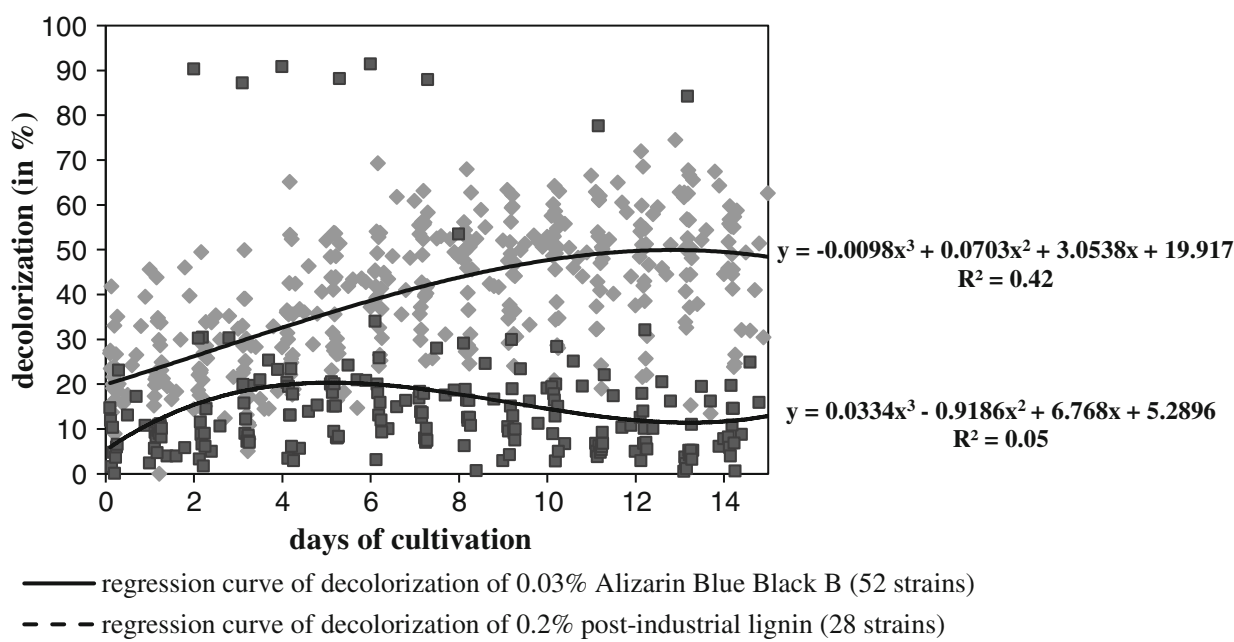

Biosynthesis of peroxidases in cultures of the fungi started already on the first day of growth. Activity of HRPlike in the presence of alizarin blue increased with the time of culturing, with a maximum on the 14th day, amounting to $90-120 \mathrm{mU} \mathrm{mg}^{-1}$ protein (Fig. 3). Activity of lignin peroxidase $(\mathrm{LiP})$ in cultures of fungi with lignin attained a maximum on the first day ( $70-160 \mathrm{mU} \mathrm{mg}^{-1}$ protein). Starting on the second day of culturing, the activity of LiP decreased gradually.

Decolorization of alizarin blue by the 52 strains of microfungi selected in our study was correlated $(\alpha=0.001)$ with increase in the activity of HRP-like peroxidase, (Table 5) so far detected (with o-dianisidine as substrate) only in cultures of white-rot basidiomycetes (Deveci et al. 2004; Shin 2004; Belcarz et al. 2005; Kornillowicz-Kowalska and Iglik 2007; Korniłłowicz-Kowalska and Rybczyńska 2012). The maximum of the catalytic activity of that enzyme in cultures of effective strains of $\mathrm{H}$. haematococca and $C$. rosea $f$. catenulata decolorizing alizarin blue was $100-140 \mathrm{mU} \mathrm{mg}^{-1}$ protein and was coincidental with the maximum of decolorization. An increase in the activity of HRP-like peroxidase during the decolorization of $0.01 \%$ remazol blue (RBBR) and daunomycin (a derivative of anthraquinone) by the anamorphic stadium of the basidiomycete Bjerkandera adusta CCBAS 930 was reported in our previous publications (Korniłłowicz-Kowalska et al. 2006; Korniłłowicz-Kowalska and Rybczyńska 2012). Participation of peroxidase oxidizing o-dianisidine as the substrate (called the non-specific peroxidase, NsP) of the white-rot basidiomycete Irpex lacteus $\mathrm{KR} 35 \mathrm{~W}$ in the process of decolorization of textile dyes was reported by Shin (2004).

The remaining peroxidase activities, $\mathrm{LiP}$ and $\mathrm{MnP}$ detected during decolorization of alizarin blue, were at a considerably lower level than the activity of HRP-like peroxidase, especially MnP. So far, there is a scarcity of (without any addition of dye substrates). 
Table 2 Decolorization of $0.2 \%$ post-industrial lignin (in \%) by selected (28 strains) microfungi in liquid cultures

\begin{tabular}{|c|c|c|c|c|c|c|c|c|c|}
\hline \multirow[t]{2}{*}{ Strains } & & \multicolumn{8}{|c|}{ Days of cultivation } \\
\hline & & $18 \mathrm{~h}$ & 2 & 4 & 6 & 8 & 10 & 12 & 14 \\
\hline \multirow[t]{19}{*}{ Haematonectria haematococca } & BS 5 & 14.72 & 90.28 & 90.83 & 91.44 & 53.49 & 19.09 & 4.97 & 7.79 \\
\hline & BS 7 & 23.14 & 30.44 & 23.44 & 25.83 & 12.61 & 20.00 & 10.12 & 14.60 \\
\hline & BS 10 & 13.12 & 5.00 & 5.66 & 10.07 & 0.73 & 6.72 & 10.12 & 8.82 \\
\hline & BS 11 & 17.24 & 10.61 & 13.90 & 14.93 & 24.61 & 25.12 & 20.51 & 24.93 \\
\hline & BS 12 & 10.77 & 30.34 & 15.33 & 16.33 & 16.67 & 19.57 & 16.18 & 15.90 \\
\hline & BS 35 & 11.91 & 30.28 & 20.39 & 34.06 & 29.11 & 19.41 & 12.55 & 8.21 \\
\hline & BS II 48 & 1.62 & 3.26 & 3.48 & 3.15 & 6.30 & 8.96 & 2.92 & 5.90 \\
\hline & Bw 28 & 6.00 & 9.00 & 17.78 & 11.97 & 12.61 & 15.00 & 7.03 & 6.87 \\
\hline & Bw III43 & 2.40 & 14.53 & 20.10 & 16.90 & 2.94 & 12.90 & 0.54 & 22.89 \\
\hline & L 25 & 10.90 & 87.22 & 88.13 & 87.94 & 29.95 & 6.75 & 5.22 & 4.47 \\
\hline & L II 13 & 5.83 & 25.36 & 20.80 & 18.63 & 11.24 & 10.33 & 6.12 & 16.32 \\
\hline & L II 21 & 5.64 & 23.28 & 20.53 & 18.36 & 10.47 & 10.81 & 3.72 & 18.51 \\
\hline & K37 & 4.73 & 9.00 & 20.10 & 13.60 & 15.07 & 77.60 & 84.20 & 23.78 \\
\hline & D3 & 9.70 & 12.22 & 15.13 & 17.94 & 18.95 & 6.25 & 5.22 & 4.07 \\
\hline & D4 & 9.00 & 7.22 & 8.13 & 7.94 & 12.95 & 4.75 & 4.22 & 4.17 \\
\hline & D6 & 11.20 & 8.20 & 8.00 & 7.04 & 9.95 & 5.35 & 4.17 & 4.27 \\
\hline & D7 & 10.50 & 8.55 & 8.10 & 7.30 & 9.05 & 6.05 & 5.26 & 3.47 \\
\hline & D8 & 8.20 & 7.30 & 9.45 & 10.10 & 7.56 & 9.22 & 11.00 & 7.32 \\
\hline & D9 & 10.10 & 7.00 & 8.35 & 7.45 & 9.95 & 6.75 & 3.22 & 4.47 \\
\hline \multirow[t]{4}{*}{ Clonostachrys rosea f. catenulata } & BS II 58 & 10.37 & 11.57 & 19.50 & 19.97 & 18.81 & 17.81 & 17.90 & 4.00 \\
\hline & BS II 74 & 4.75 & 8.76 & 13.06 & 18.06 & 16.40 & 16.43 & 14.00 & 19.70 \\
\hline & BS II 86 & 0.11 & 6.64 & 13.06 & 13.10 & 11.88 & 2.83 & 6.82 & 10.90 \\
\hline & Bw III 11 & 6.55 & 6.13 & 2.90 & 9.33 & 10.80 & 5.00 & 5.53 & 0.64 \\
\hline C. rosea f. rosea & L III 23 & 8.30 & 15.76 & 15.13 & 12.60 & 4.27 & 3.82 & 1.14 & 15.52 \\
\hline \multirow[t]{3}{*}{ Aspergillus sp. } & L II 11 & 3.95 & 19.70 & 24.20 & 27.98 & 23.44 & 22.10 & 19.50 & 33.47 \\
\hline & L II 12 & 3.95 & 20.95 & 20.93 & 17.55 & 16.22 & 17.38 & 16.20 & 29.65 \\
\hline & L II 22 & 9.27 & 19.91 & 18.13 & 13.82 & 9.51 & 5.02 & 2.22 & 8.20 \\
\hline T. harzianum & BS III 33 & 3.66 & 1.77 & 6.10 & 15.90 & 16.33 & 28.40 & 32.10 & 14.56 \\
\hline
\end{tabular}

more extensive information on the biosynthesis of peroxidases LiP, MnP, NsP in cultures of mold fungi with decolorization abilities. Only Lozovaya et al. (2006) reported the production of lignin peroxidase by $F$. solanif. sp. glycines in the process of decolorization of anthraquinone dyes: RBBR and Poly R-478.

Lignin peroxidase next to laccase was accepted to be the most important ligninolytic enzyme of white-rot basidiomycetes (Paszczyński and Crawford 1995; Robinson et al. 2001; Martinez et al. 2005). In the course of our study, we found that the level of LiP activity reached highest value in cultures of microfungi with lignin. The activities of the remaining two peroxidases, HRP-like and MnP in cultures of microfungi with lignin, were notably lower and did not show any larger variations (Tables 3, 4). The lowest activities were noted for the manganese-dependent peroxidase (Table 3). However, all 3 peroxidase activities (LiP, HRP-like, and MnP) were mutually significantly (at the highest level of significance) correlated (Table 6). A similar trend, though a weaker one $(\alpha=0.05 ; 0.01)$, was obtained for the studied peroxidase activities produced in the presence of alizarin blue (Table 5). Participation of the non-specific HRP-like peroxidase in the biodegradation of post-industrial of lignin was reported in the paper by Korniłłowicz-Kowalska et al. (2008) concerning the anamorphic stadium of B. adusta CCBAS 930. In cultures of numerous lignin-degrading white-rot fungi, the manganese-dependent peroxidase is also detected (Paszczyński and Crawford 1995; Martinez et al. 2005). The lignin(LiP) and manganese-dependent (MnP) peroxidases were produced also by 23 strains of ascomycetes degrading lignin-cellulose, in particular from the genus Coniochaeta (Lopez et al. 2007). However, none of those fungi synthesized laccase. No laccase induction in the presence of lignin was also observed in the cultures of the 52 mitosporic fungi analyzed in this study, whereas laccase was 
Fig. 2 Analysis of regression of activity of laccase (LAC) in liquid cultures of microfungi with an addition of $0.03 \%$ Alizarin Blue Black B

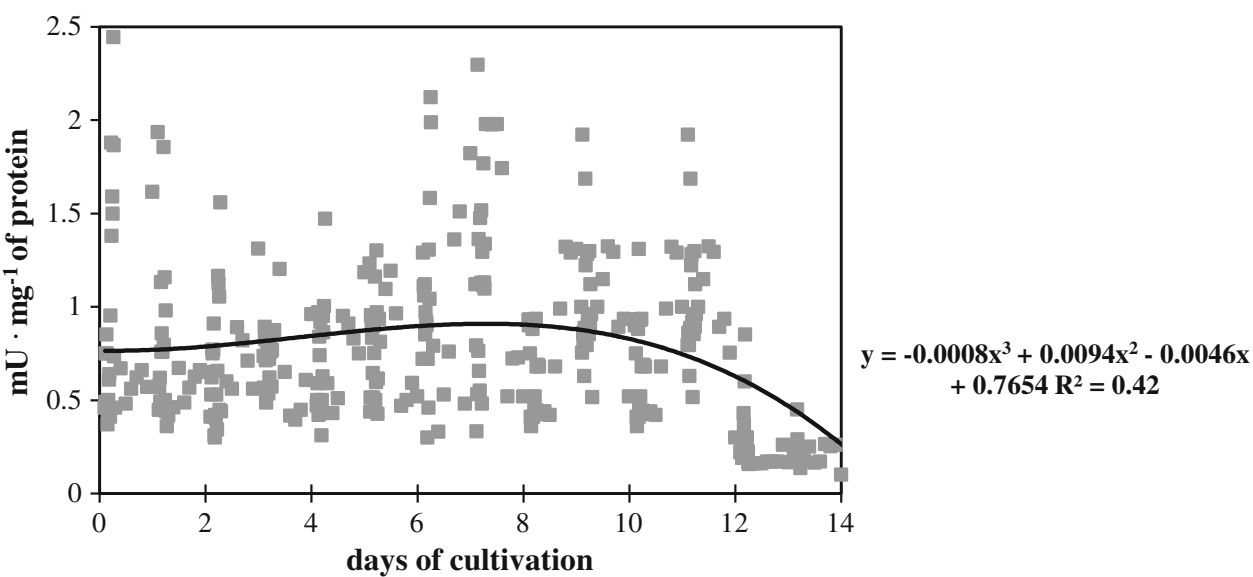

— regression curve of LAC activity in cultures with $0.03 \%$ Alizarin Blue Black B

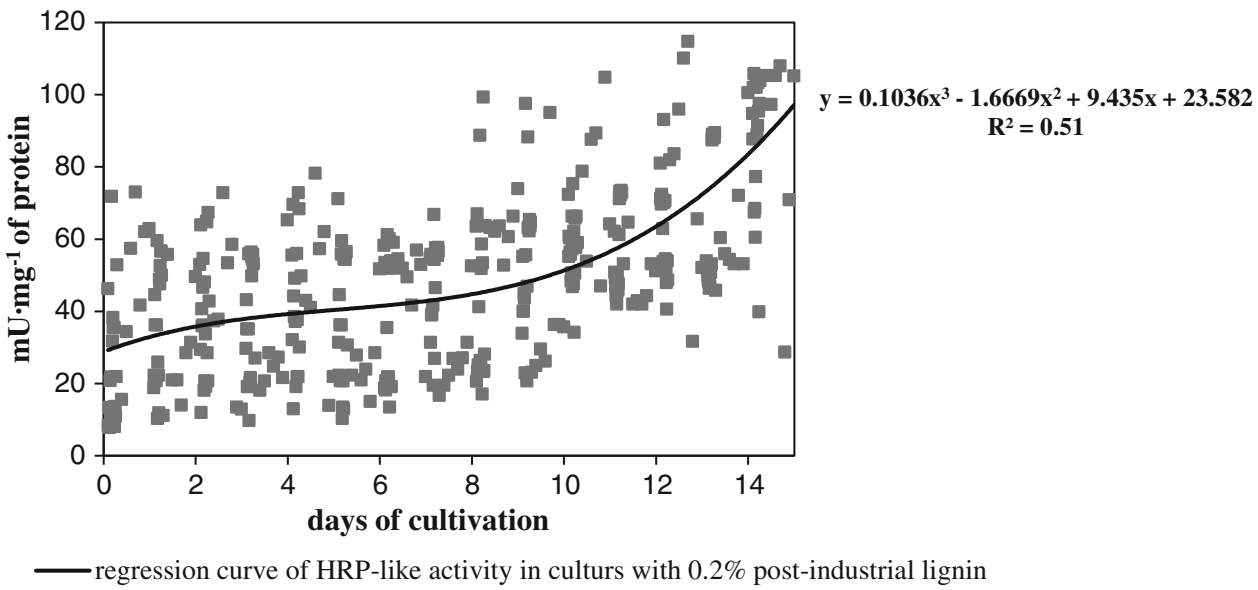

Fig. 3 Analysis of regression of activity of HRP-like peroxidases in liquid cultures of microfungi an addition of 0.03 \% Alizarin Blue Black B substrate and concerned lignin peroxidase. In both cases, higher catalytic activities were accompanied by more intensive decolorization of the substrate. Coupling of the dynamics of peroxidase ( $\mathrm{LiP}, \mathrm{MnP}$ ) and laccase activities with the degree of decolorization of textile dyes by 4 wood white-rot basidiomycetes such as B. adusta, Phlebia tremellosa, Pleurotus ostreatus, and Coriolus (Trametes) versicolor was reported earlier by Robinson et al. (2001).

In the process of biodegradation of lignin and dyes by white-rot basidiomycetes, apart from peroxidases and laccase, an important role is also played by enzymes referred to as auxiliary ones, including glucose oxidase (GOX) and catalase (CAT). Those enzymes supply (GOX) and regulate (CAT) in the environment of the reaction the concentration of $\mathrm{H}_{2} \mathrm{O}_{2}-\mathrm{a}$ co-substrate of peroxidases (Leonowicz et al. 1999; Kwon and Anderson 2001; Eichlerová et al. 2006; Lan et al. 2006).

All 52 of the selected strains, in the presence of both dye substrates, $0.2 \%$ post-industrial lignin and $0.03 \%$ alizarin blue, were characterized by an increase in the activity of under study. The reverse effect, i.e., lowering of catalytic activity, was observed in cultures with lignin as the 
Fig. 4 Analysis of regression of activity of LiP peroxidase in liquid cultures of microfungi an addition of $0.2 \%$ post-industrial lignin

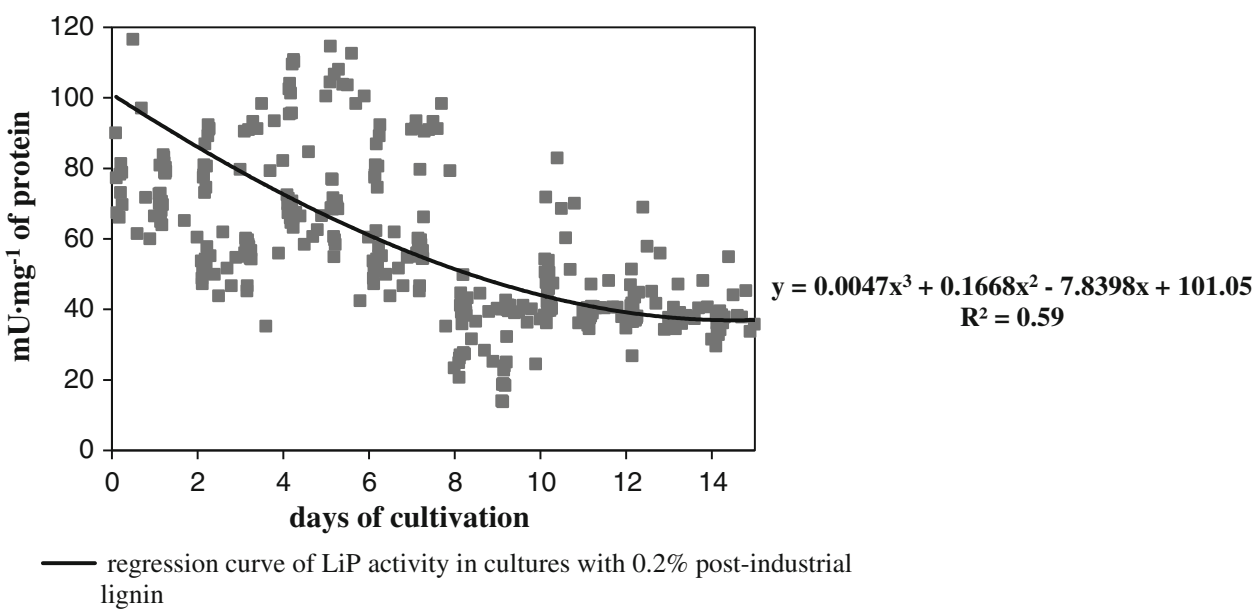

Table 3 Activity of manganese-dependent peroxidase $(\mathrm{MnP})$ in cultures of microfungi with an addition of $0.2 \%$ post-industrial lignin and $0.03 \%$ Alizarin Blue Black B

\begin{tabular}{|c|c|c|c|c|c|c|c|c|}
\hline \multirow[t]{3}{*}{ Strains } & \multicolumn{8}{|c|}{ Days of cultivation } \\
\hline & \multicolumn{4}{|c|}{$0.2 \%$ Post-industrial lignin } & \multicolumn{4}{|c|}{$0.03 \%$ Alizarin Blue Black B } \\
\hline & $18 \mathrm{~h}$ & 4 & 8 & 14 & $18 \mathrm{~h}$ & 4 & 8 & 14 \\
\hline H. haematococca $(25)^{\mathrm{b}}$ & $13.9-42.9^{\mathrm{a}}$ & $10.7-58.3$ & $9.1-32.5$ & $10.0-18.2$ & $2.3-8.9$ & $3.5-10.5$ & $3.2-12.2$ & $4.7-19.2$ \\
\hline C. rosea f. catenulatum (16) & $9.7-92.3$ & $12.9-95.9$ & $7.1-62.3$ & $10.2-18.6$ & $3.3-8.9$ & $2.2-7.8$ & $2.5-14.1$ & $5.4-12.9$ \\
\hline C. rosea f. rosea (5) & $26.3-51.9$ & $23.0-73.4$ & $18.9-53.7$ & $15.3-17.1$ & $3.3-6.3$ & $4.6-7.4$ & $4.1-12.7$ & $7.9-12.9$ \\
\hline Aspergillus sp. (3) & $25.2-28.2$ & $18.9-28.3$ & $11.7-21.5$ & $13.1-18.5$ & $2.5-3.9$ & $2.0-10.4$ & $8.1-10.9$ & $4.7-15.4$ \\
\hline A. spinosa (1) & 30.7 & 23.8 & 22.6 & 10.6 & 5.8 & 6.6 & 8.7 & 6.7 \\
\hline P. cyclosporus (1) & 24.7 & 21.6 & 18.6 & 14.1 & 7.2 & 6.2 & 7.9 & 19.1 \\
\hline T. harzianum (1) & 10.1 & 8.8 & 7.1 & 9.7 & 3.3 & 7.0 & 10.9 & 10.6 \\
\hline
\end{tabular}

${ }^{a} \mathrm{MnP}$ activity ( $\mathrm{mU} \mathrm{mg}^{-1}$ of protein)

${ }^{\mathrm{b}}$ Number of strains

GOX, notably stronger during the decolorization of alizarin blue (Fig. 5). In the presence of lignin, the activities of GOX were very low (1-10 $\mathrm{mU} \mathrm{mg}^{-1}$ protein), whereas the maximum activity of that enzyme in cultures with the dye was 35-45 $\mathrm{mU} \mathrm{mg}^{-1}$ protein. It was observed on the 4-6th days of growth of the fungi and was coincidental with increase in activity of HRP-like peroxidase. There was no significant correlation between the activities of those two enzymes through the period of culturing, even though toward the end of the culturing, another slight increase appeared in the activity of glucose oxidase (Table 5), whereas the activity of GOX was significantly ( $\alpha=0.001)$, though weakly, correlated with decolorization of alizarin blue (Table 5). The relatively high coefficient of determination $\left(R^{2}=0.51\right)$ for GOX activity in the cultures of the microfungi strains on the medium with $0.03 \%$ alizarin blue (Fig. 5), with a rather low coefficient of total variability of that feature $(\mathrm{Cv}=17.30-35.65 \%)$, indicates a high strain similarity of the selected microfungi (52 isolates) in terms of the dynamics and level of biosynthesis of the enzyme. Moreover, the efficiency of production of that enzyme was correlated, tough weakly, with the productivity of lignin peroxidase (Tables 5, 6). Correlation between the activities of those two enzymes during the biodecolorization of synthetic dyes was demonstrated also by Lan et al. (2006) in experiments on the decolorization of fuchsine and rhodamine B by Phanerochaete chrysosporium ATCC 34541. Gomaa et al. (2011) observed that the decolorization effectiveness of a strain of Aspergillus sp. toward Basic Blue increased with increasing activity of glucose oxidase. Eichlerová et al. (2006) point out that not only ligninolytic enzymes but also hydrogen peroxide and free radicals are responsible for the degradation of organic contaminants. Perhaps, the high activity of glucose oxidase producing $\mathrm{H}_{2} \mathrm{O}_{2}$ (with a lack of activity of catalase) observed in the cultures with alizarin blue also contributed 
Table 4 Activity of peroxidases: LiP i HRP-like of cultures of microfungi an addition $0.2 \%$ post-industrial lignin and $0.03 \%$ Alizarin Blue Black B

\begin{tabular}{|c|c|c|c|c|}
\hline \multirow[t]{2}{*}{ Strains } & \multicolumn{4}{|c|}{$0.2 \%$ Post-industrial lignin (days of cultivation) } \\
\hline & $18 \mathrm{~h}$ & 4 & 8 & 14 \\
\hline H. haematococca $(25)^{\mathrm{c}}$ & $24.3-40.6^{\mathrm{a}}$ & $22.2-39.7$ & $5.2-20.2$ & $15.5-24.2$ \\
\hline C. rosea $f$. catenulatum (16) & $23.3-42.6$ & $29.8-37.3$ & $13.2-22.7$ & $20.6-23.3$ \\
\hline C. rosea f. rosea (5) & $23.4-39.9$ & $23.4-41.50$ & $12.0-14.4$ & $16.1-23.2$ \\
\hline Aspergillus sp. (3) & $34.6-36.2$ & $38.0-38.3$ & $8.2-13.3$ & $16.7-18.4$ \\
\hline A. spinosa (1) & 37.5 & 41.4 & 16.9 & 18.2 \\
\hline P. cyclosporus (1) & 35.5 & 37.5 & 13.0 & 18.5 \\
\hline T. harzianum (1) & 33.7 & 19.8 & 17.8 & 17.6 \\
\hline \multicolumn{5}{|c|}{$0.03 \%$ Alizarin Blue Black B (days of cultivation) } \\
\hline H. haematococca $(25)$ & $13.1-109.8^{\mathrm{b}}$ & $15.9-49.8$ & $7.9-54.9$ & $15.1-62.4$ \\
\hline C. rosea $f$. catenulatum (16) & $9.5-42.8$ & $11.9-63.7$ & $14.0-46.3$ & $15.3-179.7$ \\
\hline C. rosea f. rosea (5) & $8.8-62.1$ & $27.8-49.2$ & $20.2-69.7$ & $16.6-116.1$ \\
\hline Aspergillus sp. (3) & $12.5-35.5$ & $11.9-31.7$ & $19.9-271$ & $25.7-34.2$ \\
\hline A. spinosa (1) & 5.9 & 27.8 & 22.1 & 23.4 \\
\hline P. cyclosporus (1) & 5.9 & 31.7 & 27.1 & 23.4 \\
\hline T. harzianum (1) & 15.4 & 13.8 & 16.7 & 19.4 \\
\hline
\end{tabular}

${ }^{a}$ HRP-like activity ( $\mathrm{mU} \mathrm{mg}^{-1}$ of protein)

${ }^{\mathrm{b}}$ LiP activity ( $\mathrm{mU} \mathrm{mg}^{-1}$ of protein)

c Number of strains

to more effective decolorization of that dye as compared to the decolorization of lignin. In cultures with post-industrial lignin, low activities of glucose oxidase were noted (at a high activity of catalase), and its decolorization was weaker compared to alizarin blue.

The strains of micromycetes studied synthesized catalase (CAT) only in cultures with an addition of $0.2 \%$ postindustrial lignin (Fig. 6). Biosynthesis of the enzyme started already on the first day of the culture and intensified, attaining a maximum toward the end of the second week of culturing (usually from 100 to $160 \mathrm{mU} \mathrm{mg}^{-1}$ protein) (Fig. 6). Estimation of changes in catalase activity with the method of regression (Fig. 6) revealed that the biosynthesis of that enzyme in the cultures of the 52 strains of micromycetes was at a relatively similar level $\left(R^{2}=0.54\right)$, displaying variability at the level of $\mathrm{Cv}=14.15-35.64 \%$, which, in about $70 \%$, was related to the strains. The activity of the enzyme was significantly $(\alpha=0.001)$ negatively, though weakly, correlated with the level of activity of the peroxidases and of glucose oxidase (Table 6).

The role of catalase in biodegradation of lignin and structurally related aromatic compounds is not, however, fully researched yet. Nevertheless, it is known that it regulates the concentration of $\mathrm{H}_{2} \mathrm{O}_{2}$ in the environment of peroxidase reactions (Kwon and Anderson 2001). The fact of detection of catalase activity only in the variant with
Table 5 Correlation coefficients $(r)$ between the analyzed traits selected (28 strains) of microfungi growing in the presence of $0.2 \%$ post-industrial lignin

\begin{tabular}{llllll}
\hline Feature & HRP-like & MnP & LiP & GOX & CAT \\
\hline Decolorization & \multirow{2}{*}{0.08} & 0.02 & -0.03 & 0.07 & -0.04 \\
HRP-like & & $0.19^{* * *}$ & $0.65^{* * *}$ & $0.39^{* * *}$ & $-0.44^{* * *}$ \\
MnP & & & 0.03 & 0.07 & $-0.31^{* * *}$ \\
LiP & & & & $0.27^{* * *}$ & $-0.43^{* * *}$ \\
GOX & & & & & $-0.24 * * *$ \\
\hline
\end{tabular}

$* * *$ Correlation significance level $\alpha=0.001$

lignin may also be related with the peroxidase properties of that enzyme, consisting in, among other things, the oxidation of quinones liberated during the biodegradation of lignin, which was reported by Bartosz (2003), and in consequence its decolorization. In the course of our study, we found also that catalase activity was negatively though weakly correlated with the activities of HRP-like, manganese-dependent, and lignin peroxidases (Table 6).

Based on the results obtained in this study, we can state that certain strains of microfungi have similar or even stronger decolorization capabilities compared to wood white-rot fungi and may have potential significance in the bioremediation of aquatic environments. The most 
Fig. 5 Analysis of regression of activity of glucose oxidase (GOX) in liquid cultures of microfungi with content of postindustrial lignin and Alizarin Blue Black B

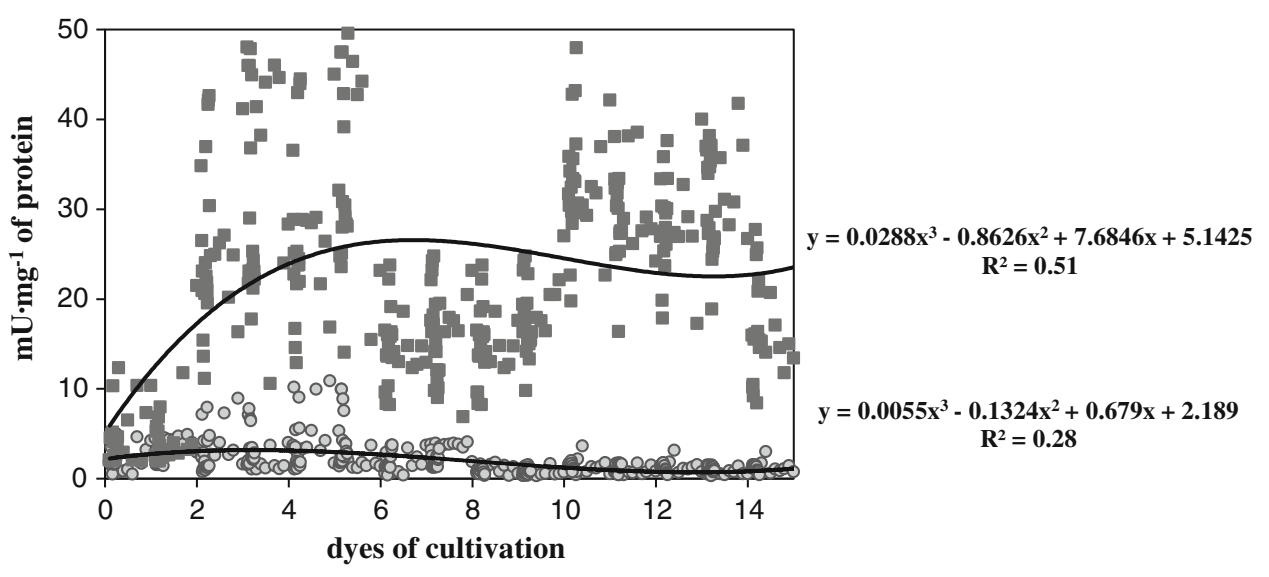

- - - regression curve of GOX activity in cultures with $0.2 \%$ post-industrial lignin

- regression curve of GOX activity in cultures with $0.03 \%$ Alizarin Blue Black B

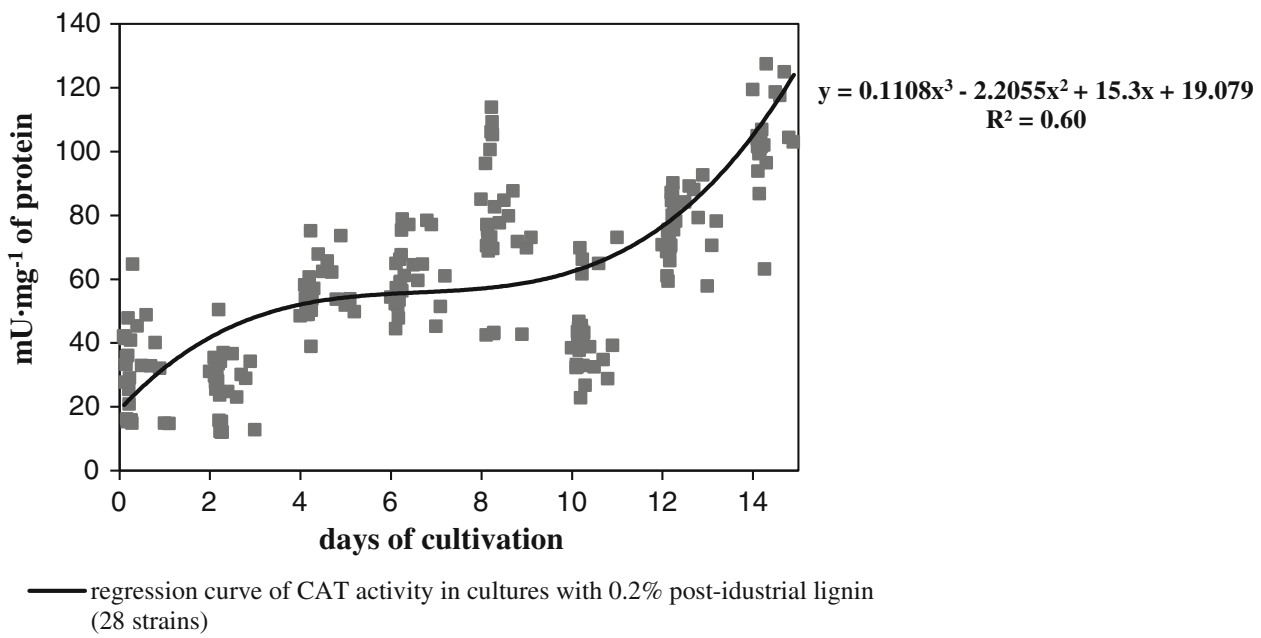

Fig. 6 Analysis of regression of activity of catalase (CAT) in liquid cultures of microfungi an addition $0.2 \%$ post-industrial lignin 
The selected strains in cultures containing alizarin blue were characterized by a high activity of HRP-like peroxidase and glucose oxidase, with a very low activity of laccase and no activity of catalase, which was accompanied by decolorization of that dye. It was found that the activities of LiP in cultures of the fungi under study were significantly and positively, though weakly, correlated with the activity of HRP-like, MnP, and glucose oxidase, and negatively with catalase. It was also demonstrated that the activities of the detected phenoloxidases, glucose oxidase, and catalase were characterized by notable strain-related differentiation. Among the 52 selected strains, three, i.e., H. haematococca, BwIII43 and $\mathrm{K} 37$, and T. harzianum BsIII33, proved to be the most promising for the purposes of decolorization of industrial effluents.

Acknowledgments This work was partially financed by the Polish National Center of Science (Project No. N N304 292440).

Open Access This article is distributed under the terms of the Creative Commons Attribution License which permits any use, distribution, and reproduction in any medium, provided the original author(s) and the source are credited.

\section{References}

Abedin RMA (2008) Decolorization and biodegradation of crystal violet and malachite green by Fusarium solani (Martius) Saccardo. A comparative study on biosorption of dyes by the dead fungal biomass. Am-Eurasian J Bot 1:17-31

Aebi H (1984) Catalase in vitro. Methods Enzymol 1-5:121-126

Allen NS, McKellar JF (1978) The photochemistry of commercial polyamides. J Polym Sci Macromol Rev 13:241-281

Amat AM, Arques A, Miranda MA, Lopez F (2005) Use of ozone and/or UV in the treatment of effluents from board paper industry. Chemosphere 60:1111-1117

Anastasi A, Pirigione V, Casieri L, Varese GC (2009) Decolourisation of model and industrial dyes by mitosporic fungi in different culture condition. World J Microbiol Biotechnol 25:1363-1374

Andleeb S, Atiq N, Robson GD, Ahmed S (2012) An investigation of anthraquinone dye biodegradation by immobilized Aspergillus flavus in fluidized bed bioreactor. Environ Sci Pollut Res 19:1728-1737

Bartosz G (2003) The second face of oxygen. Free radicals in nature, 2th ed. Warsaw, PWN SA (in polish)

Belcarz R, Ginalska G, Korniłłowicz-Kowalska T (2005) Extracellular enzyme activities of Bjerkandera adusta R59 soil strain, capable for daunomycin and humic acids degradation. Appl Microbiol Biotechnol 68:686-694

Bi R, Spadiut O, Lawoko M, Brumer H, Henriksson G (2012) Isolation and identification of microorganisms from soil able to live on lignin as a carbon source and to produce enzymes which cleave the $\beta-\mathrm{O}-4$ bond in a lignin model compound. Cellul Chem Technol 46:227-242

Biyik H (2012) Biological decolorization of textile dyes from isolated microfungi. J Environ Biol 33:667-671

Chakar FS, Ragauskas AJ (2004) Review of current and future softwood kraft lignin process chemistry. Ind Crops Prod 20:131-140
Champagne PP, Ramsay JA (2005) Contribution of manganese peroxidase and laccase to dye decolorization by Trametes versicolor. Appl Microbiol Biotechnol 69:276-285

Colombo JC, Cabello M, Arambarri AM (1996) Biodegradation of aliphatic and aromatic hydrocarbons by natural soil microflora and pure cultures of imperfect and lignolitic fungi. Environ Pollut 94(3):355-362

Deveci T, Unyayar A, Mazmanci MA (2004) Production of Remazol Brilliant Blue $\mathrm{R}$ decolourising oxygenase from the culture filtrate of Funalia trogii ATCC 200800. J Mol Catal B Enzym 30:25-32

Domsch KH, Gams W, Anderson TH (1980) Compendium of soil fungi, vol 1. Acad. Press, London

Eichlerová I, Homolka L, Lisá L, Nerud F (2005) Orange G and Remazol Brilliant Blue $\mathrm{R}$ decolorization by white rot fungi Dichomitus squalens, Ischnoderma resinosum and Pleurotus calyptratus. Chemosphere 60:398-404

Eichlerová I, Homolka L, Lisa L, Nerud F (2006) The influence of extracellular $\mathrm{H}_{2} \mathrm{O}_{2}$ production on decolorization ability in fungi. J Basic Microbiol 46:449-455

Eichlerová I, Homolka L, Nerud F (2007) Decolorization of high concentration of synthetic dyes by the white rot fungus Bjerkandera adusta strain CCBAS 232. Dyes Pigment 75:38-42

Falcón MA, Rodriguez A, Carnicero A, Regaldo V, Perestelo F, Milstein O, De La Fuente G (1995) Isolation of microorganism with lignin transformation potential from soil of Tenerife island. Soil Biol Biochem 27:121-126

Freitag M, Morrell JJ (1992) Decolorization of the polymeric dye Poly R-478 by wood-inhabiting fungi. Can J Microbiol 38:811-822

Gao H, Wang Y, Zang W, Wang W, Mu Z (2011) Isolation, identification and application in lignin degradation of an ascomycete GHJ-4. Afr J Biotechnol 10:4166-4174

Garg SK, Modi DR (1999) Decolorization of pulp-paper mill effluents by white-rot fungi. Crit Rev Biotechnol 19:95-112

Gomaa OM, Momtaz OA, Kareem HAE, Fathy R (2011) Isolation, identification, and biochemical characterization of a brown rot fungus capable of textile dye decolorization. World J Microbiol Biotechnol 27:1641-1648

Guzel B, Akgerman A (2000) Mordant dyeing of wool by supercritical processing. J Supercrit Fluids 18:247-252

Holme I (2002) Recent developments in colorants for textile applications. Surf Coat Int B Coat Trans 85:243-332

http://www.indexfungorum.org

Husseiny ShM (2008) Biodegradation of the reactive and direct dyes using Egyptian isolates. J Appl Sci Res 4:599-606

Jarosz-Wilkołazka A, Kochmańska-Rdest J, Malarczyk E, Wardas W, Leonowicz A (2002) Fungi and their ability to decolorize azo and anthraquinonic dyes. Enzyme Microb Technol 30:566-572

Kant R (2012) Textile dyeing industry an environmental hazard. Nat Sci 4:22-26

Korniłłowicz-Kowalska T, Iglik H (2007) Decolourisation of synthetic dye water solution by mutagenised strain Bjerkandera adusta R59. Pol J Environ Stud 16:472-482

Korniłłowicz-Kowalska T, Rybczyńska K (2012) Decolorization of Remazol Brilliant Blue (RBBR) and Poly R-478 dyes by Bjerkandera adusta CCBAS 930. Cent Eur J Biol 7:948-956

Korniłłowicz-Kowalska T, Wrzosek M, Ginalska G, Iglik H, Bancerz $\mathrm{R}$ (2006) Identification and application of a new fungal strain Bjerkandera adusta R59 in decolorization of daunomycin wastes. Enzyme Microb Technol 38:583-590

Korniłłowicz-Kowalska T, Ginalska G, Belcarz A, Iglik H (2008) Decolorization of humic acid and alkaline lignin derivative by an anamorphic Bjerkandera adusta R59 stain isolated from soil. Pol J Environ Stud 60:903-909

Kwaśna H, Chełkowski J, Zajkowski P (1991) Polish flora. Fungi (Mycota) XXII, (Deuteromycetes), (Hyphomycetales), (Fusarium). Lublin: Acad Press UP (in polish) 
Kwon SJ, Anderson AJ (2001) Catalase activities of Phanerochaete chrysosporium are not coordinately produced with ligninolytic metabolism: catalase from a white-rot fungus. Curr Microbiol 42:8-11

Lan J, Huang X, Hu M, Li Y, Qu Y, Gao P, Wu D (2006) High efficient degradation of dyes with lignin peroxidase coupled with glucose oxidase. J Biotechnol 123:483-490

Leonowicz A, Grzywnowicz K (1981) Quantitative estimation of laccase in some white-rot fungi using syringaldazine as a substrate. Enzyme Microb Technol 3:55-58

Leonowicz A, Matuszewska A, Luterek J, Ziegenhagen D, WojtaśWasilewska M, Cho N-S et al (1999) Biodegradation of lignin by white rot fungi: review. Fungal Gen Biol 27:175-185

Lloyd JB, Whelan WJ (1969) Enzymatic determination of glucose in presence of maltose. Anal Biochem 30:467-470

Lopez MJ, Guisado G, Vargas-Garcia MC, Suárez-Estrella F, Moreno J (2006) Decolorization of industrial dyes by ligninolytic microorganisms isolated from composting environment. Enzyme Microb Technol 40:42-45

Lopez MJ, Vargas-García MC, Suárez-Estrella F, Nichols NN, Dien BS, Moreno J (2007) Lignocellulose-degrading enzymes produced by the ascomycete Coniochaeta ligniaria and related species: application for a lignocellulosic substrate treatment. Enzyme Microb Technol 40:794-800

Lowry JOH, Rosenbrought NJ, Forr AL, Randal PJ (1954) Protein measurement with Folin phenol reagent. J Biol Chem 193:265-270

Lozovaya VV, Lygin AV, Zernova OV, Li S, Widholm JM (2006) Lignin degradation by Fusarium solani f. sp glycines. Plant Dis 90:70-82

Maehly AC, Chance B (1954) The assay of catalases and peroxidases. In Glick D (ed) Methods of biochemical analysis 1, Interscience Publish Inc, New York, pp 357-66

Malarczyk E (1984) Substrate-induction of veratric acid O-demethylase in Nocardia sp. Acta Biochem Polon 31:383-395

Martinez AT, Speranza M, Ruiz-Duenas FJ, Ferreira P, Camarero S, Guillen $F$ et al (2005) Biodegradation of lignocellulosics: microbial, chemical and enzymatic aspects of fungal attack in lignin. Int Microbiol 8:195-204

Nemerow NL, Dasgupta A (1991) Industrial and hazardous waste treatment. Van Nostrand Reinhold, New York

Neoh CH, Yahya A, Adnan R, Majid ZA, Ibrahim Z (2012) Optimization of decolorization of palm oil mill effluent (POME) by growing cultures of Aspergillus fumigatus using response surface methodology. Environ Sci Pollut Res. doi:10.1007/ s11356-012-1193-5

Norris DM (1980) Degradation of ${ }^{14} \mathrm{C}$-labeled lignins and ${ }^{14} \mathrm{C}$-labeled aromatic acids by Fusarium solani. Appl Environ Microbiol 40:376-380
Park D, Robinson PM (1969) Sporulation in Geotrichum candidum. Trans Br Mycol Soc 52:213-222

Paszczyński A, Crawford RL (1995) Potential for bioremediation of xenobiotic compounds by the white-rot-fungus Phanerochaete chrysosporium. Biotechnol Prog 11:368-379

Pokhrel D, Viraraghavan T (2004) Treatment of pulp and paper mill wastewater-a review. Sci Total Environ 333:37-58

Raju NS, Venkataramane GV, Girish ST, Raghavendra VB, Shivashankar P (2007) Isolation and evaluation of indigenous soil fungi for decolorization of textile dyes. J Appl Sci 7:298-301

Rigas F, Dritsa V (2006) Decolourisation of a polymeric dye by selected fungal strains in liquid cultures. Enzyme Microb Technol 39:120-124

Robinson T, Chandran B, Nigam P (2001) Studies on the production of enzymes by white-rot fungi for the decolourisation of textile dyes. Enzyme Microb Technol 29:575-579

Rodriguez A, Perestelo F, Carnicero A, Regaldo V, Perez R, De la Fuente $G$ et al (1996) Degradation of natural lignins and lignocellulosic substrates by soil-inhabiting fungi imperfecti. FEMS Microbiol Ecol 21:213-219

Shin KS (2004) The role of enzymes produced by white-rot fungus Irpex lecteus in the decolorization of textile industry effluent. J Microbiol 42:37-41

Tien T, Kirk K (1988) Lignin peroxidase of Phanerochaete chrysosporium. Methods Enzymol 161:238-249

Uddin MK, Hossain MS (2010) A comparative study on silk dyeing with acid dye and reactive dye. Int J Eng Technol 10:21-26

Waffaa M, Abd-El R, Moawad H, Khalafellah MA (2003) Microflora involved in textile dye waste removal. J Basic Microbiol 43:167-174

Wariishi H, Valli K, Gold HM (1992) Manganese (II) oxidation by manganese peroxidase from the Basidiomycete Phanerochaete chrysosporium. J Biol Chem 267:23685-23695

Westermark U, Eriksson KE (1974) Carbohydrate-dependent enzymic quinone reduction during lignin degradation. Acta Chem Scand B 28:204-208

Wu Y-R, Luo Z-H, Vrijmoed LLP (2010) Biodegradation of anthracene and benz[a]anthracene by two Fusarium solani strains isolated from mangrove sediments. Bioresour Technol 101:9666-9672

Yemendzhiev H, Alexieva Z, Krastanov A (2009) Decolorization of synthetic dye Reactive Blue 4 by mycelia culture of white-rot fungus Trametes versicolor 1. Biotechnol Biotechnol Equip 23:230-232 